This is an author produced version of a paper published in Environmental Management.

This paper has been peer-reviewed and is proof-corrected, but does not include the journal pagination.

Citation for the published paper:

Östberg, Johan; Delshammar, Tim; Wiström, Björn; Busse Nielsen, Anders. (2013) Grading of Parameters for Urban Tree Inventories by City Officials, Arborists, and Academics Using the Delphi Method. Environmental Management. Volume: 51, Number: 3, pp 694-708. http://dx.doi.org/10.1007/s00267-012-9973-8.

Access to the published version may require journal subscription. Published with permission from: Springer.

Standard set statement from the publisher:

"An author may self-archive an author-created version of his/her article on his/her own website and or in his/her institutional repository. He/she may also deposit this version on his/her funder's or funder's designated repository at the funder's request or as a result of a legal obligation, provided it is not made publicly available until 12 months after official publication. He/ she may not use the publisher's PDF version, which is posted on www.springerlink.com, for the purpose of self-archiving or deposit. Furthermore, the author may only post his/her version provided acknowledgement is given to the original source of publication and a link is inserted to the published article on Springer's website. The link must be accompanied by the following text: "The final publication is available at www.springerlink.com".

Epsilon Open Archive http://epsilon.slu.se 


\title{
Grading of parameters for urban tree inventories by city officials, arborists and academics using the Delphi method
}

Östberg*, Johan $^{1}$. Delshammar, Tim ${ }^{1}$. Wiström, Björn ${ }^{1}$. Nielsen, Anders Busse ${ }^{1}$.

\footnotetext{
${ }^{1}$ Swedish University of Agricultural Sciences, Faculty of Landscape Planning, Horticulture and Agricultural Science, Department of Landscape Management, Design and Construction, Box 66, SE-23053 Alnarp, Sweden.

*Corresponding author
}

\begin{abstract}
Tree inventories are expensive to conduct and update, so every inventory carried out must be maximized. However, increasing the number of constituent parameters increases the cost of performing and updating the inventory, illustrating the need for careful parameter selection. This paper reports the results of a systematic expert rating of tree inventories aiming to quantify the relative importance of each parameter. Using the Delphi method, panels comprising city officials, arborists and academics rated a total of 148 parameters. In order of total mean score, the top ranking parameters, which can serve as a guide for decision-making at practical level and for standardization of tree inventories, were: Scientific name of the tree species and genera, Vitality, Coordinates, Hazard class and Identification number.
\end{abstract}

The study also examined whether the different responsibilities and usage of urban tree databases among organizations and people engaged in urban tree inventories affected their prioritization. The results revealed noticeable dissimilarities in the ranking of parameters between the panels, underlining the need for collaboration between the research community and those commissioning, administrating and conducting inventories. Only by applying such a transdisciplinary approach to parameter selection can urban tree inventories be strengthened and made more relevant.

\section{Introduction}

Trees contribute to the delivery of many ecosystem services in urban areas, such as moderation of local climate (Nowak et al. 2006; Dimoudi and Nikolopoulou 2003; Yokohari et al. 2001; Nowak et al. 2001), stormwater management (Xiao and McPherson 2002; Bolund and Hunhammar 1999), recreation and human well-being (Todorova et al. 2004), and cultural 
values (Alcamo et al. 2003). Long-term management and renewal of urban trees is therefore crucial for sustainable urban development.

The basis for this work is tree management programs. To support sound urban tree management programs, high quality information is needed (Martin et al. 2011; Schipperijn et al. 2005; Miller 1997). In recognition of this, an increasing number of city administrations, especially in North America and Europe, have started to conduct extensive inventories of their tree stocks in street environments, but also in parks and other settings (Sjöman et al. 2012; Schipperijn et al. 2005). The information is typically compiled into databases used by local authorities to gain an overview of the urban tree stock. It is then used to inform the planning and prioritization of day-to-day management activities and the development of longterm management objectives and strategies (Miller 1997), but also as a tool to help quantify and communicate the values and services provided by urban trees (Keller and Konijnendijk 2012). Urban tree inventories are an important tool for decision-making and knowledge development related to e.g., mapping of storm-damaged trees and identification of the most affected species and dimensions (Jim and Liu 1997), risk management (i.e. minimizing damage to persons and property (Mattheck and Breloer 1994; Lonsdale 1999), and assessment of tree species diversity (Sjöman et al. 2012). The latter is often coupled with pest and disease monitoring and risk analysis (Raupp et al. 2006). Urban tree inventories are also increasingly used by researchers to model the contribution of urban trees to ecosystem services, e.g., related their capacities to counter-act the urban heat island effect at local scales (Yokohari et al. 2001; Dimoudi and Nikolopoulou 2003), reduce the energy costs for indoor winter heating and summer cooling (McPherson et al. 1997), capture air pollution (McPherson et al., 1997; Nowak et al. 2006); and decrease stormwater runoff (McPherson et al. 1997). Urban tree inventories can also be used in determining the economic value of individual trees (CTLA 2000; Cullen 2002; Randrup 2005) and the overall economic benefits trees provide to urban societies (Maco and McPherson 2003; i-Tree 2012). The many usages of urban tree inventories are by no means mutually exclusive, yet they reflect different valuations of urban forests and the goals of the specific tree inventory, which ultimately influence prioritization and selection of inventory parameters.

As tree inventories are expensive to conduct and update, it is important to make the most out of every inventory performed. However, the greater the number of parameters to be measured and archived, the more expensive the inventory becomes. A recent comparative analysis of tree inventories from the 10 largest cities in the Nordic countries showed that their 
inventories included between 20 and 25 parameters. Further examination revealed noticeable differences between the cities with respect to the type of parameters included. In fact, as many as 49 parameters were identified, only two of which were included by all cities, namely Species and Classification into street trees and park trees. A similar picture is likely to apply for other regions.

While the extensive number of parameters used in previous urban tree data collection and reporting is probably an illustration of a high level of ambition, it also indicates a lack of consensus about the parameters that are the most useful. This might reflect the fact that different user groups are involved in the design of inventories. Initiatives have therefore been taken to standardize urban tree inventories (Östberg et al. 2012a; Thomsen 2012; UNRI 2010). However, no previous study has attempted to rank the vast numbers of inventory parameters measured in terms of priority, so as to guide standardization efforts. Similarly, few studies have investigated how differences in responsibilities for urban tree databases and their use between commissioning agents and administrators of tree inventories (city officials), providers of tree care (arborists), and urban forestry researchers and teachers (academics) affect their prioritization of parameters to be included in the urban tree inventories (Maruthaveeran and Yaman 2010; Sjöman and Nielsen 2010; Starr 1990). The present study sought to fill these knowledge gaps through a systematic expert rating of tree inventory parameters at national level in Sweden. The study was designed to (1) provide a reliable group prioritization of inventory parameters among experts, and (2) identify differences in ratings between the main groups of experts engaged in urban tree inventory. More specifically, the study was guided by the following two research questions:

- Which parameters do experts rate as being the most relevant to include in urban tree inventories?

- Does the rating of parameters deviate between different user groups, i.e. city officials, arborists, and academics?

\section{Materials and methods}

The study was conducted in two steps. The first of these comprised a screening of tree inventory parameters and their definitions (see below). These parameters were then fed into a Delphi survey, where three expert panels separately rated the relative importance of the individual parameters for inclusion in a large-scale inventory of trees in urban streets and parks. 


\section{Screening of tree inventory parameters}

The screening stage generated a total of 124 parameters (Appendix 1). These parameters were compiled from a wide range of urban tree databases, tree inventory guidelines, and scientific literature. By screening different sources of information, such as the tree databases for 10 of the largest cities in the Nordic countries (Sjöman et al. 2012), the Urban Forestry Data Standards 2.0 supported by the USDA (UNRI 2010), and tree risk manuals (Forbes-Laird 2010; Smiley et al. 2007), we ensured that a wide range of different parameters were identified. See Östberg et al. (2012a) for a full list of the sources reviewed.

The parameters were then classified into six thematic groups:

a) Descriptive inventory parameters, i.e. spatial, qualitative, and quantitative descriptions such as tree location, species, DBH (diameter at breast height), and height.

b) Vitality and safety, i.e. assessments of damage to trees, their vitality, and the risk of the tree itself causing damage.

c) Tree values, i.e. assessments of biological, aesthetic, and cultural values, etc.

d) Measures and maintenance needs, i.e. recommendations for management activities such as irrigation and pruning.

e) Database metadata, i.e. inventory metadata, such as when the tree inventory was last performed and by whom.

f) Documentation of management, i.e. notes on management such as the nursery from which the tree was procured, when it was planted, and the maintenance after planting.

\section{Delphi survey}

The Delphi method is an established qualitative research technique that seeks to provide a reliable group opinion through the use of expert judgment (Landeta 2006). The first Delphi study was performed in the 1950s (Dalkey and Helmer 1963) and since then a large number of research fields have used the method, including e.g. medical science (Graham et al. 2003) organization science (Nevo and Chan 2007), and environmental science (Bryant and Abkowitz 2007). It has also been used recently in the areas of urban green structure science (James et al. 2009), forest preference research (Edwards et al. 2012) and assessment of hazard tree parameters (Maruthaveeran and Yaman 2010).

The steps in the Delphi process used in this study were adapted from Okoli and Pawlowski (2004), who describe the methodology for identification and categorization of experts, and 
from Graham et al. (2003), who describe the method for rating of parameters. The survey was conducted in parallel in three separate panels, judged by the authors to represent different responsibilities for, and interest in, tree inventories. These were: a) employees at city administrations procuring and managing urban tree care and urban tree inventories (hereafter termed 'city officials'); b) arboricultural companies and consultants (hereafter termed 'arborists'); and c) researchers and teachers at universities and other educational and research institutions (hereafter termed 'academics').

\section{Identification and categorization of expert panels}

The snowball method (Okoli and Pawlowski 2004) was used to collect information on suitable experts. Initially, a list of members of the Swedish tree care association was acquired from the Swedish chapter of the International Society of Arboriculture (ISA). This list was supplemented by suggestions from research colleagues. Each person on the list was then contacted and asked to suggest experts on urban trees. The search followed a standardized procedure:

- Step 1: One phone call

- Step 2: One e-mail

- Step 3: Three phone calls during one day

- Step 4: Three phone calls during one other day

People not reached after these steps were removed from the list. The search generated a list of 78 experts, of which 18 were city officials, 51 were arborists, and 9 were academics at the Swedish University of Agricultural Sciences. Because of the limited number of academics and their affiliation to the same university, the search was broadened to include research establishments in the neighboring countries of Denmark, Finland, and Norway, resulting in 24 academics in total.

The experts were classified according to specific criteria for each panel. The city officials were classified according to: (1) their knowledge (formal or practical), (2) the geographical region of Sweden in which they worked, and (3) their range of different knowledge skills. The arborists were classified according to: (1) their knowledge (different types of backgrounds), (2) their knowledge as consultants and practitioners, (3) whether they had a background in large or small businesses, and (4) the geographical region of Sweden in which they worked. The academics were classified according to: (1) their research knowledge 
regarding urban trees (also including different types of knowledge, for example plant pathology, soil science, method development, and plant nurseries), and (2) the Nordic country in which they worked.

The aim was to select experts with reliable knowledge on urban trees, but also with a variety of perspectives. The authors then selected 10 experts from each group to achieve panel sizes similar to that of other Delphi studies (e.g. Edwards et al. 2012). After some hesitation from one of the academic panelists and one of the city officials, an extra panelist was selected for each of these two panels, resulting in a total of 32 panelists. Of these panelists, 24 took part in the whole study (8 city officials, 9 arborists, and 7 academics). The dropouts were mainly caused by participants' workload outside the Delphi study.

A flow chart of the selection process and the number of experts rated is presented in Figure 1. 


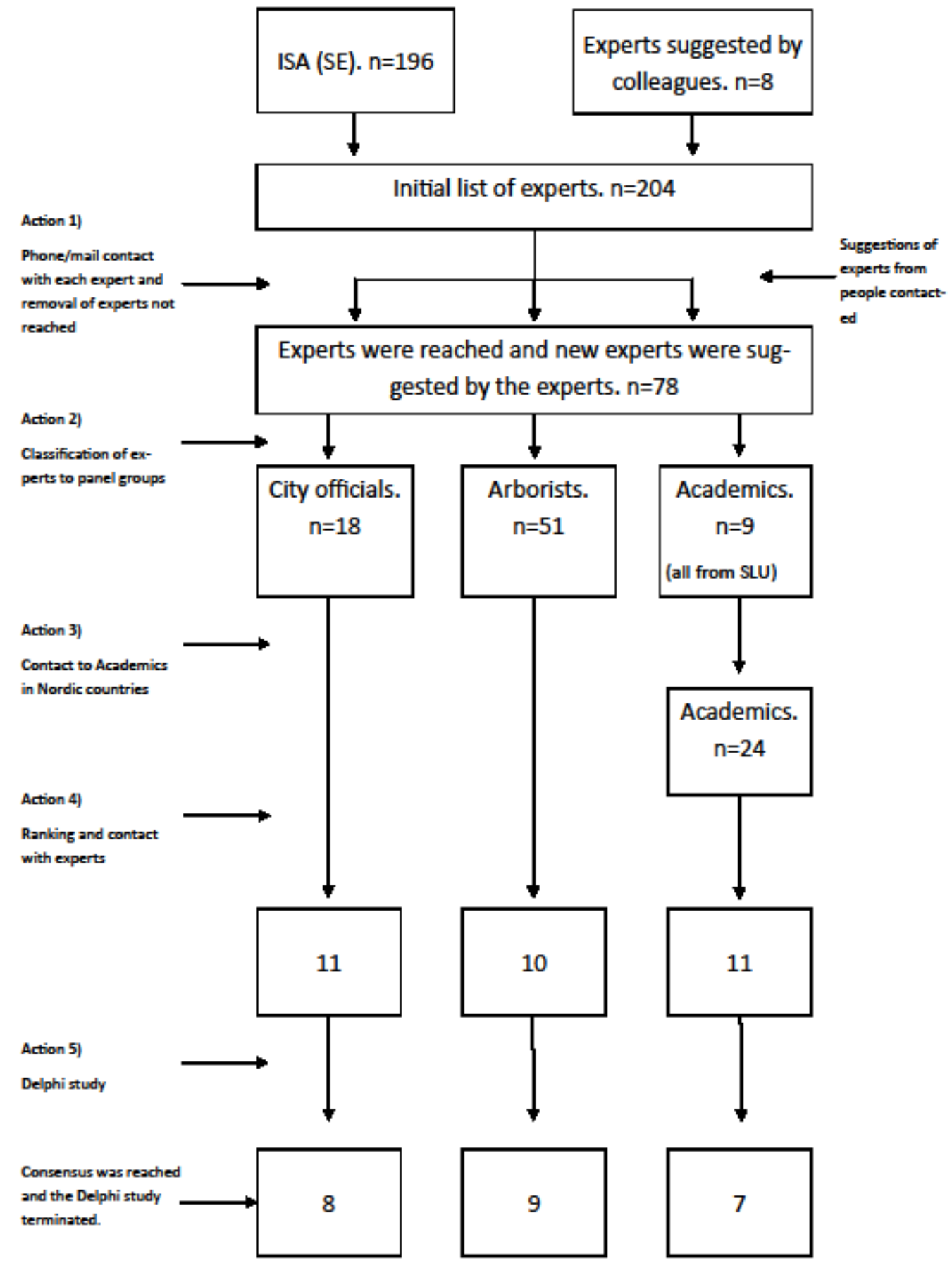

Figure 1. Flow chart showing the selection process for identification, characterization, and selection of experts for the Delphi study. 


\section{Delphi rating}

Directly after an expert had agreed to take part in the study, a detailed description of the project was e-mailed to him/her, together with the list of tree inventory parameters. The list contained all 124 tree inventory parameters identified in the screening phase, together with a short description and an example of how each parameter could be used. The panelists were asked to suggest and describe any missing parameters. In this way the list was expanded to 148 parameters. (The inclusion of new parameters is further described in Appendix 1.)

The adjusted list of parameters was e-mailed as an Excel document to the panelists and they were asked to rate all tree inventory parameters on a scale from 1 to 10 , where 1 was not important and 10 was very important. When rating the parameters, the panelists were asked to consider the inventory parameters to be used in a large-scale urban tree inventory, where large-scale was defined as more than 5000 trees, in both park and street environments. The panelists were given the opportunity to write short comments on each parameter, as this has been shown to support the panelists in reaching consensus in earlier studies (Rohrbaugh 1979).

Before the second round of rating, the ratings by individual panelists were compiled for each panel, so they could see the (anonymous) ratings of the other experts in their panel. The panelists were then instructed to rate each parameter again, especially considering parameters where their previous rating deviated considerably from the mean value of the panel.

\section{Analysis of Delphi data}

To determine when consensus was achieved, standardized Cronbach's alpha was used with a coefficient $>0.8$ for the individual panels (SAS 9.2, SAS institute Inc.). Cronbach's alpha is a measurement of agreement, with a coefficient of 1 signifying total agreement. The value obtained for Cronbach's alpha is dependent on the number of items, and therefore needs to be adjusted for the specific dataset (Cortina 1993). Based on the Cronbach's alpha value from Graham et al. (2003) and advice from statistical experts, in the present study the coefficient was set to 0.8 , which is generally considered good internal consistence (George and Mallery 2008).

The first round of rating resulted in a Cronbach's alpha value of 0.7497 for the city officials, 0.7752 for the arborists, and 0.7245 for academics. The second round of rating resulted in a Cronbach's alpha value of 0.9009 for the city officials, 0.8984 for the arborists, and 0.8600 
for the academics, and the Delphi survey was therefore terminated after the second round of rating.

To test whether the panels were individual panels before the first rating and whether the grouping of parameters (group A-F) was valid, a discriminant analysis (SPSS 20.0, IBM) of the panels was performed for each parameter group after the first round of rating. For all parameter groups the classification into the panels had a hit ratio of $>90 \%$. This indicates that the panels were individual panels before the study began and not an arbitrary construction by the authors. The grouping of the parameters also emerged as coherent groupings. The differences between panels and parameter groups after the Delphi study ended were therefore tested by pair-wise comparisons using the Friedman test. The response was the mean score for each parameter within each Delphi panel and the individual parameter was used as the block.

To identify the key parameters separating the three panels after the Delphi study was terminated, a step-wise discriminant analysis (SPSS 20.0, IBM) was performed for each parameter group (group A-F). Minimization of Wilks' lambda was used as the method, where the minimum partial F-value to enter a parameter was set to 3.84 and the maximum for removal to 2.71 .

The step-wise discriminate analysis identified Free text as one of the explanatory variables in five out of six parameter groups. (Free text means an opportunity to include notes that are not predefined. All Free text parameters are attached to a predefined parameter as an opportunity to write further information and details.) Accordingly, Free text was added as a parameter group, meaning that seven parameter groups were tested (parameters A-F and Free text).

The top 25 parameters for each panel and overall were then extracted for more detailed analysis. The decision to select 25 parameters reflected the number of parameters included in tree inventories in the largest Swedish cities of Gothenburg (25), Malmö (26), and Stockholm (20), as well as other Scandinavian and North American cities studied by Keller and Konijnendijk (2012). In order to qualify and validate our interpretation of differences in the top 25 parameters between the panels, the list was presented for, and discussed with, representatives from each expert group.

\section{Results}


Comparisons of mean value for the parameter groups showed that parameter group $\mathrm{F}$ (Documentation of management) received the lowest mean rating from all panels. Group D (Measures and maintenance needs) was the highest rated group for the city officials, while the Free text parameter was rated highest by the academics and the arborists. In contrast, the city officials rated the Free text parameter second lowest (Table 1).

The pair-wise comparisons showed that parameter group B (Vitality and safety) was the only group upon which the three panels agreed, while the ratings deviated significantly between the panels for parameters in group A (Descriptive inventory parameters), group $\mathrm{F}$ (Documentation of management) and Free text. The ratings by city officials and arborists deviated the most, only agreeing on parameter group B. The academics and the arborists agreed on four of the parameter groups (Table 1).

Table 1. Parameter group according to the list presented in the Materials \& Methods section, together with mean rating for the three panels and how well the panelists agreed on the rating according to a multiple pair-wise comparison.

The letters a, b, and c show the agreement between panels (based on the Friedman test), with the same letter indicating agreement between the panels and parameter groups.

\begin{tabular}{lrrr}
\hline Parameter group & $\begin{array}{r}\text { City } \\
\text { officials }\end{array}$ & Arborists & Academics \\
\hline A- Descriptive inventory parameters & $5.5^{\mathrm{a}}$ & $6.6^{\mathrm{c}}$ & $7.3^{\mathrm{b}}$ \\
B- Vitality and safety & $6.2^{\mathrm{a}}$ & $7.8^{\mathrm{a}}$ & $7.9^{\mathrm{a}}$ \\
C- Tree values & $5.3^{\mathrm{a}}$ & $6.7^{\mathrm{b}}$ & $6.7^{\mathrm{b}}$ \\
D- Measures and maintenance needs & $6.6^{\mathrm{a}}$ & $7.8^{\mathrm{b}}$ & $7.0^{\mathrm{ab}}$ \\
E- Database metadata & $6.1^{\mathrm{a}}$ & $7.0^{\mathrm{b}}$ & $7.1^{\mathrm{b}}$ \\
F- Documentation of management & $3.5^{\mathrm{a}}$ & $4.3^{\mathrm{c}}$ & $3.8^{\mathrm{b}}$ \\
Parameters on Free text & $5.4^{\mathrm{a}}$ & $8.4^{\mathrm{c}}$ & $8.8^{\mathrm{b}}$ \\
\hline
\end{tabular}

\section{Top 25 parameters according to overall mean}

Of the 25 parameters that received the highest mean value overall, parameters from Group A (Descriptive inventory parameters) were most frequent for all tree panels, with 8, 5, and 6 respectively for the city officials, academics, and arborists. However, the academics and arborists had the same amount of parameters from Group B (Vitality and safety). In comparison, the parameter group with the lowest number of parameters in the top 25 list varied between the panels. It was Group C (Tree values) for the city officials, with 2 parameters; Group F (Documentation of management) for the academics, with 1 parameter; and Group E (Database) for the arborists, with 1 parameter (Table 2). 
Only the parameter Scientific name of the tree species and genera received a rating of 10.0 from all three panels. For the city officials, Coordinates also received 10.0 and for the academics three other parameters received 10.0, namely Identification number, Date of latest inventory, and Date of first inventory. The arborists did not give 10.0 to any other parameter.

Among the individual parameters included in the overall top 25 list, some noticeable differences in ratings were observed between the panels. In the mean overall ranking by the three panels, Year of planting was ranked in place 19, but the panel of city officials ranked it 5, the academics 27, and the arborists 99. The three parameters Date of registration in the database, Date of update in the database, and Date of latest inventory, belonging to the group Database, were also rated very low by the arborists, 105, 69, and 50, respectively, compared with 25, 20, and 7 as the overall for the three panels. The Street or park tree parameter and Stem circumference at 1 meter height at planting deviated. The Street or park tree parameter was ranked in place 7 by the city officials, 29 by the academics, and 40 by the arborists. Stem circumference at 1 meter height at planting deviated in a similar way, being placed 8 by the city officials, 51 by the academics, and 24 by the arborists. The city officials also deviated from the two other panels when it came to the parameter Free text (on hazard and damage), which they placed at 54, compared with 6 for the academics and 10 for the arborists (Table 2).

Two of the extra parameters added by the panelists were among the 25 parameters that received the overall highest mean values. These were Type of constructed planting site (place 16) and Soil protection around the tree (place 22).

The total mean values for all parameters differed between the panels. The city officials gave a mean of 5.8 for all parameters, the academics 7.1, and the arborists 7.0, compared with the overall mean of 6.7 for all parameters (Appendix 1). The mean for the top 25 parameters was 8.7 overall, 8.6 for the city officials, 9.6 for the academics, and 9.2 for the arborists (Table 2). 
Table 2. The parameters listed and their mean ranking. Codes in brackets indicate membership of one of six different groups of parameters $(\mathbf{A}=$ Descriptive inventory parameters, $\mathbf{B}=$ Vitality and safety, $\mathbf{C}=$ Tree values, $\mathbf{D}=$ Measures and maintenance, $\mathbf{E}=$ Database metadata, $\mathbf{F}=$ Documentation of management). After the mean overall ranking for all parameters, the ranking of the parameter by the three panels $(\mathbf{C O}=$ City officials, $\mathbf{A C}=$ Academics, $\mathbf{A R}=$ Arborists $)$ is given in brackets. All parameters are listed in order of prioritization by the three panels.

\begin{tabular}{|c|c|c|c|c|c|c|c|c|}
\hline $\begin{array}{l}\text { Parameter } \\
\text { placement for } \\
\text { the different } \\
\text { panels }\end{array}$ & $\begin{array}{l}\text { Parameter according to } \\
\text { mean value }\end{array}$ & $\begin{array}{l}\text { Mean rating and } \\
\text { placement in the } \\
\text { individual panels }\end{array}$ & City officials & Mean & Academics & Mean & Arborists & Mean \\
\hline 1 & $\begin{array}{l}\text { Scientific name of the tree } \\
\text { species and genera }(\mathrm{A})\end{array}$ & 10.0 (CO:1 AC:1 AR:1) & $\begin{array}{l}\text { Scientific name of the tree } \\
\text { species and genera }(A)\end{array}$ & 10.0 & $\begin{array}{l}\text { Scientific name of the } \\
\text { tree species and } \\
\text { genera }(\mathrm{A})\end{array}$ & 10.0 & $\begin{array}{l}\text { Scientific name of the tree } \\
\text { species and genera }(\mathrm{A})\end{array}$ & 10.0 \\
\hline 2 & Vitality (B) & 9.8 (CO:3 AC:5 AR:2) & Coordinates (A) & 10.0 & $\begin{array}{l}\text { Identification number } \\
\text { (E) }\end{array}$ & 10.0 & Vitality (B) & 9.8 \\
\hline 3 & Coordinates (A) & 9.6 (CO:2 AC:9 AR:11) & Vitality (B) & 9.8 & $\begin{array}{l}\text { Date of latest } \\
\text { inventory }(E)\end{array}$ & 10.0 & Identification number $(\mathrm{E})$ & 9.8 \\
\hline 4 & Hazard class (B) & 9.4 (CO:4 AC:19 AR:6) & Hazard class (B) & 9.5 & $\begin{array}{l}\text { Date of first inventory } \\
\text { (E) }\end{array}$ & 10.0 & Name of disease or pest (B) & 9.7 \\
\hline 5 & Identification number $(\mathrm{E})$ & $9.2(\mathrm{CO}: 26 \mathrm{AC}: 2 \mathrm{AR}: 3)$ & Year of planting $(\mathrm{A})$ & 9.4 & Vitality (A) & 9.9 & $\begin{array}{l}\text { Free text concerning the time } \\
\text { factor for the maintenance } \\
\text { and operations (D) }\end{array}$ & 9.7 \\
\hline 6 & Presence of fruit bodies (B) & $\begin{array}{l}9.0(\mathrm{CO}: 17 \text { AC:11 } \\
\text { AR:7) }\end{array}$ & $\begin{array}{l}\text { Date of latest inventory } \\
\text { (E) }\end{array}$ & 9.0 & $\begin{array}{l}\text { Free text on hazard } \\
\text { and damage }(\mathrm{B})\end{array}$ & 9.9 & Hazard class $(\mathrm{B})$ & 9.6 \\
\hline 7 & Date of latest inventory $(\mathrm{E})$ & 9.0(CO:6 AC:3 AR:50) & Street or park trees (A) & 9.0 & $\begin{array}{l}\text { Date of registration in } \\
\text { the database }(E)\end{array}$ & 9.9 & Presence of fruit bodies (B) & 9.6 \\
\hline 8 & Category of care (D) & $\begin{array}{l}9.0(\mathrm{CO}: 11 \text { AC: } 12 \\
\text { AR:23) }\end{array}$ & $\begin{array}{l}\text { Stem circumference at } 1 \\
\text { metre height at planting } \\
\text { (A) }\end{array}$ & 8.9 & $\begin{array}{l}\text { Free text on diseases } \\
\text { and pests }(B)\end{array}$ & 9.9 & $\begin{array}{l}\text { Free text on new planting of } \\
\text { trees }(F)\end{array}$ & 9.4 \\
\hline 9 & Conservation value $(\mathrm{C})$ & $\begin{array}{l}9.0(\mathrm{CO}: 12 \text { AC: } 20 \\
\text { AR:13) }\end{array}$ & Type of planting pit (A) & 8.9 & Coordinates (A) & 9.7 & $\begin{array}{l}\text { Free text on the cultural value } \\
\text { of the tree }(C)\end{array}$ & 9.3 \\
\hline 10 & Street or park trees (A) & 8.8(CO:7 AC:29 AR:40) & Protection value $(\mathrm{C})$ & 8.8 & Damage class $(\mathrm{B})$ & 9.7 & Proposed measures (D) & 9.2 \\
\hline 11 & Age class (A) & $\begin{array}{l}\text { 8.7(CO:21 AC:21 } \\
\text { AR:14) }\end{array}$ & Category of care (D) & 8.6 & $\begin{array}{l}\text { Presence of fruit } \\
\text { bodies (B) }\end{array}$ & 9.6 & Coordinates (A) & 9.1 \\
\hline 12 & $\begin{array}{l}\text { Stem circumference at } 1 \\
\text { meter height at planting }(\mathrm{A})\end{array}$ & 8.7(CO:8 AC:51 AR:24) & Conservation value $(\mathrm{C})$ & 8.6 & Category of care (D) & 9.6 & Establishment pruning $(\mathrm{F})$ & 9.1 \\
\hline 13 & Date of planting $(\mathrm{F})$ & $\begin{array}{l}\text { 8.6(CO:16 AC: } 22 \\
\text { AR:30) }\end{array}$ & $\begin{array}{l}\text { Type of constructed } \\
\text { planting site }(F)\end{array}$ & 8.4 & $\begin{array}{l}\text { Free text on tree } \\
\text { damage (B) }\end{array}$ & 9.6 & Conservation value $(\mathrm{C})$ & 9.0 \\
\hline
\end{tabular}


Date of registration in the 8.3 AR:36) database $(\mathrm{E})$

Free text on tree conservation value $(\mathrm{C})$

Free text concerning the time factor for the 9.4 Age class (A) maintenance and

Ground coverage under the tree crown (A)

\begin{tabular}{|c|c|c|c|c|c|c|c|c|}
\hline & & & & & operations (D) & & & \\
\hline 16 & $\begin{array}{l}\text { Type of constructed } \\
\text { planting site }(F)\end{array}$ & $\begin{array}{l}\text { 8.4(CO:13 AC: } 48 \\
\text { AR:43) }\end{array}$ & Date of planting $(\mathrm{F})$ & 8.1 & $\begin{array}{l}\text { Free text on inventory } \\
\text { information }(\mathrm{A})\end{array}$ & 9.4 & Name of fungi (B) & 9.0 \\
\hline 17 & Proposed measures (D) & $\begin{array}{l}\text { 8.3(CO:14 AC: } 72 \\
\text { AR:10) }\end{array}$ & $\begin{array}{l}\text { Presence of fruit bodies } \\
\text { (B) }\end{array}$ & 8.0 & $\begin{array}{l}\text { Free text on tree } \\
\text { management (D) }\end{array}$ & 9.4 & Protected by law (C) & 9.0 \\
\hline 18 & Street address (A) & $\begin{array}{l}\text { 8.3(CO:29 AC: } 45 \\
\text { AR:33) }\end{array}$ & Reason of felling (E) & 8.0 & $\begin{array}{l}\text { Free text concerning } \\
\text { the identification and } \\
\text { local (A) }\end{array}$ & 9.4 & Damage class, detailed (B) & 9.0 \\
\hline 19 & Year of planting (A) & 8.2(CO:5 AC:37 AR:99) & $\begin{array}{l}\text { Date of update in the } \\
\text { database (E) }\end{array}$ & 8.0 & Hazard class (B) & 9.3 & $\begin{array}{l}\text { Free text on hazard and } \\
\text { damage (B) }\end{array}$ & 8.8 \\
\hline 20 & $\begin{array}{l}\text { Date of update in the } \\
\text { database }(E)\end{array}$ & $\begin{array}{l}\text { 8.2(CO:19 AC: } 23 \\
\text { AR:69) }\end{array}$ & $\begin{array}{l}\text { Proposals for action, time } \\
\text { (D) }\end{array}$ & 8.0 & $\begin{array}{l}\text { Conservation value } \\
\text { (C) }\end{array}$ & 9.3 & Proposals for action, time (D) & 8.8 \\
\hline 21 & $\begin{array}{l}\text { Presence of stem protection } \\
\text { (A) }\end{array}$ & $\begin{array}{l}\text { 8.2(CO:22 AC:31 } \\
\text { AR:61) }\end{array}$ & Age class $(\mathrm{A})$ & 7.9 & Age class (A) & 9.3 & Free text on tree vitality (A) & 8.8 \\
\hline 22 & $\begin{array}{l}\text { Soil protection around the } \\
\text { tree }(A)\end{array}$ & $\begin{array}{l}8.1(\mathrm{CO}: 32 \text { AC:38 } \\
\text { AR:44) }\end{array}$ & $\begin{array}{l}\text { Presence of stem } \\
\text { protection }(A)\end{array}$ & 7.9 & Date of planting $(\mathrm{F})$ & 9.3 & $\begin{array}{l}\text { Free text on diseases and } \\
\text { pests (B) }\end{array}$ & 8.8 \\
\hline 23 & $\begin{array}{l}\text { Free text on hazard and } \\
\text { damages (B) }\end{array}$ & 8.1(CO:54 AC:6 AR:19) & $\begin{array}{l}\text { Irrigation programme for } \\
\text { trees }(\mathrm{F})\end{array}$ & 7.9 & $\begin{array}{l}\text { Date of update in the } \\
\text { database (E) }\end{array}$ & 9.3 & Category of care (D) & 8.7 \\
\hline 24 & Owner(E) & $\begin{array}{l}\text { 8.1(CO:28 AC:58 } \\
\text { AR:29) }\end{array}$ & $\begin{array}{l}\text { Contractor for planting } \\
\text { (F) }\end{array}$ & 7.8 & $\begin{array}{l}\text { Free text on cultural } \\
\text { value of the trees }(\mathrm{C})\end{array}$ & 9.3 & $\begin{array}{l}\text { Stem circumference at } 1 \\
\text { metre height at planting (A) }\end{array}$ & 8.7 \\
\hline 25 & $\begin{array}{l}\text { Date of registration in the } \\
\text { database }(E)\end{array}$ & $\begin{array}{l}\text { 8.1(CO:15 AC:7 } \\
\text { AR:105) }\end{array}$ & Identification number $(\mathrm{E})$ & 7.8 & $\begin{array}{l}\text { Free text on tree } \\
\text { aesthetics }(\mathrm{C})\end{array}$ & 9.3 & Pruning (D) & 8.7 \\
\hline & Mean & 8.7 & Mean & 8.4 & Mean & 9.2 & Mean & 8.6 \\
\hline
\end{tabular}




\section{Changes and comments on parameters}

The number of comments made on the individual tree inventory parameters in the Delphi study varied between the panels. The city officials commented in the first rating on a mean of 20 parameters per panelist (range 0-92 comments). In round two this number increased to a mean of 34 (range 0-92). The arborists commented on a mean of 4 parameters (range 0-10) in the first round, and this increased to a mean of 12 (range 0-57) in the second round. The academics commented on a mean of 5 parameters (range 0-18) in the first round and on a mean of 9 (range $0-18$ ) in the second round.

The number of changed ratings in the Delphi study varied between the panels. The city officials changed a mean of 64 ratings (range 0-114 ratings), the arborists 48 (range 1-99), and the academics 37 (range 0-90).

\section{Discussion}

\section{Parameter groups}

The different responsibilities and usages for urban tree inventories represented by the three panels evidently affected their rating of the parameter groups. Thus the results reaffirm that communication between the stakeholders is crucial for successful design and usage of tree inventories (Schipperijn et al. 2005). Group D (Measures and maintenance needs) was rated highest by city officials, but not by the two other panels (Table 1). This is probably a consequence of city officials having the responsibility for planning and funding tree management (e.g. Pokorny 2003; Miller 1997). However, the panels agreed upon the importance of the parameter group B (Vitality and safety), which was rated second highest by all three panels. This is likely to reflect the fact that the risk of trees causing damage or injuries is generally one of the determining factors in conducting or updating inventories of the urban tree stock (Keller and Konijnendijk 2012; Thomsen 2012; Pokorny 2003).

All panels gave a low rating to group F (Documentation of management). This was somewhat surprising, considering that management actions (or lack of action) often directly affect the vitality and safety status of urban trees. A likely explanation, confirmed by the panels, relates to the demand for continuous updating over time (Miller 1997). This interpretation is further supported by the fact that group E (Database metadata) received an intermediate rating. Compared with documentation of management actions for individual trees, database metadata are relatively easy to maintain. 
The relatively low rating of group $\mathrm{C}$ (Tree values) might reflect the fact that tree inventories are mainly used as a management tool, whereas their potential use in more strategic planning largely remains to be exploited in the Scandinavian countries (e.g. Thomsen 2012).

The group of parameters that stands out is Free text. While the city officials consistently gave this group very low ratings, the arborists and the academics rated Free text highest of all parameter groups. When discussing the study results with the academics, it emerged that their high ranking of Free text reflected an interest in nuances. However, the academics were also aware of the trade-offs needed, as city officials have to think of what is practically possible. Thus updating of inventory parameters, and especially free text parameters, is a common challenge to achieving the goals and aims of tree inventories and keeping them valid and useful over time (Keller and Konijnendijk 2012). As an illustration of this, one of the city official panelists argued that: "Inclusion of free text parameters would be great, but it is not possible to keep them updated. It is a question of self-preservation compared to the other panels who are more dreamers." While the arborists in principle agreed with this statement, they regarded free text as important when an inventory is to be updated, and argued that in the absence of free text, tree inventories would need to be extended to include a number of other parameters in order to prevent important information from being lost over time.

The city officials were generally more cautious about giving higher scores. Their mean rating was 5.3, compared with 7.3 for the academics and 7.0 for the arborists. A likely explanation is that the city officials, being the group that purchases and manages tree inventories, have been influenced by actual inventories (which include only about 25 parameters or less) and know the challenges involved in updating these inventories (Keller and Konijnendijk 2012). However, the city officials had a higher Cronbach's alpha value than the other two panels and were more willing to change their rating. It is therefore also possible that their lower scores were linked to a 'desire' to achieve consensus.

\section{Individual parameters}

The extensive number of inventory parameters identified in the initial screening (148) illustrates the tough decision-making needed when parameters are to be selected for inclusion in urban tree inventories. The panelist ranked 6-7 times more parameters than are normally included in an inventory. Our main contribution in this respect was to overcome this difficulty and quantify the relative importance of each parameter using rigorous methodology. The parameters that obtained the highest rankings therefore deserve further 
attention. As mentioned, a reasonable cut-off was the top 25 parameters, as this reflects the upper limit for number of parameters included in most urban tree inventories.

Broadly speaking, the top 25 parameters presented in Table 2 are supported by the literature. For example, the top-rated parameters Scientific name (ranked 1 overall), Coordinates (ranked 3), and Identification number (ranked 5) are commonly used in the published literature, illustrating agreement on the importance of parameters that ensure systematic registration and documentation of tree locations (Sreetheran et al. 2011; Hsu 1997; Sudol and Zach 1987). Similarly, the use of Vitality (ranked 2), Hazard class (ranked 4), and Presence of fruit bodies of fungi (ranked 6) in the scientific literature supports their high ranking (Terho and Hallaksela 2008; Terho et al. 2007). However, there were some outliers. One parameter that illustrates this is $D B H$. On reviewing the literature, $D B H$ is among the parameters most commonly used in scientific studies of e.g., economic benefit calculations (iTree 2012), climate management (Ningal et al. 2010), and air pollution (Diem and Comrie 1998), indicating its relevance for city officials and academics. However, in the Delphi ranking $D B H$ was only rated 103 . While this result is difficult to explain fully, it might be a reflection of the fact that cities use other parameters to measure tree size, e.g., diameter at 1 meter, crown diameter, or tree height. However, this parameter also achieved a low ranking (105), as did the remaining two measures of stem size; stem circumference at $1.3 \mathrm{~m}$ height (120) and stem diameter at $1 \mathrm{~m}$ height (146) (see Appendix 1). The low ranking of all four parameters for the data category 'stem size' might indicate that while the panelists agreed that stem size was an important category to be included in urban tree inventories, they disagreed about the best parameter to measure it.

Our expectation was that the city officials and the arborists would have a much more practical attitude than the academics and that this would be revealed in higher rating of parameters such as Pruning. However, the academics gave the highest score of 9.1 to this parameter, compared with 6.5 for the city officials and 8.7 for the arborists. In subsequent discussions, it was revealed that the city officials had rated the parameter low mainly because of their experience of the difficulties in keeping it updated.

\section{Limitations}

The study achieved a systematic expert rating of urban tree inventory parameters, with the Delphi method being applied to allow broader conclusions to be drawn. The number of panelists that took part in the whole study (24) was higher than that in Graham et al. (2003), 
where 13 panelists took part, and in line with Edwards et al. (2012), where 10 experts made up each panel. The number of panelists, together with the careful selection process, reduced the risk of individual panel members having a significant impact on the scores. The panelists were instructed to rate the inventory parameters independently to avoid ranking of parameters in comparison with other parameters, e.g., a high value on branch growth but not on tree vitality, because the panelist regarded branch growth as a measure of tree vitality. However, the instruction might also have implied that important data fields where many alternative parameters were provided obtained low rankings because the panelists disagreed about the parameter to measure it. As discussed above, this was likely to be the case for the four different measures of stem size. Furthermore, the panelists were asked to rate the parameters for use in a large-scale urban tree inventory, without further specification of the purpose of the inventory, so the rankings should be interpreted with caution.

While the above aspects set obvious limitations on the validity of the ranking of individual parameters and its validity for inventories with an explicit focus, such as hazard tree management (Lonsdale 1999), economic valuation (Randrup 2005), or conflicts between trees and urban infrastructure (Östberg et al. 2012b), we believe that by not having a stated purpose, the experts' rankings were more likely to express the overall relevance of the individual parameters for inclusion in urban tree inventories.

The study is by necessity dependent on limitations of time and place. As an example, it is worth mentioning that very few Swedish municipal park departments would have considered risk tree management an issue only a few years ago, while before Dutch elm disease very few considered invasive plant diseases a problem. This indicates that the motives for tree inventories are continuously evolving and that the underlying reason for conducting tree inventories and prioritization of inventory parameters to be included can change. Related to this, threats related to climate change and air pollutants, but also opportunities related to technological developments, are likely to add new relevant parameters and change prioritization among parameters to be included in urban tree inventories in the future.

\section{Conclusions}

The rankings presented in this study appear to provide a reliable prioritization of inventory parameters, where the top 25 parameters can serve as a guide for standardization efforts in Sweden. As many of the parameters included in the top 25 list are mentioned in studies from other countries around the world, such as Finland (Terho and Hallaksela 2008), Malaysia 
(Maruthaveeran and Yaman 2010), and the USA (Martin et al. 2011), the rankings can also serve as a guide for international standardization of urban tree inventories. However, the study would benefit from being repeated in other countries. Similarly, repeating the Delphi study for urban tree inventories at smaller and larger scales (e.g., an individual street/park, cities of varying sizes, and national surveys) could help validate the results of this study and ultimately identify an appropriate number of inventory parameters which can still yield the data necessary to promote effective urban tree management programs. Such standards could reduce the costs of data collection and analysis and facilitate future comparison of urban forest between cities and countries. In a wider perspective, standardization also has the potential to support the development of other urban forest tools.

On a more detailed level, the study revealed distinct dissimilarities in the ranking of parameters between city officials, arborists, and academics. Keeping in mind the differences in responsibility for, and use of, urban tree databases, these dissimilarities are understandable, but problems can arise if the gap between the groups becomes too wide. In relation to this, the differences identified and the indicative explanations given improve our ability to capture the divergent agendas within urban forestry more fully. Broadly speaking, the results emphasize the need for collaboration between the research community and those commissioning, conducting, and managing inventories. Only by applying a transdisciplinary approach to the selection of parameters can urban tree inventories can be strengthened and made more relevant. We propose that the agenda be broadened to related disciplines and research agendas, so as to maximize the usability of urban tree inventories as data sources for assessment of the many ecosystem services provided by urban forests.

\section{Acknowledgements}

The authors want to thank research assistants Cecilia Ek and Johanna Lööw for the sometimes frustrating job of gathering information on experts conducting the snowball method.

We also want to thank all of the participants in the Delphi study: Anders Ohlsson Sjöberg, Anna Flatholm, Anu Riikonen, Arne Mattson, Björn Embrén, Dan Haubo, Elisabeth Lindkvist, Garry Lindquist, Harald Kratschmer, Henrik Morin, Henrik Sjöman, Klaus Schneider, Klaus Stritzke, Michael Jackson, Oliver Bühler, Per Anker Pedersen, Stefan Lagerqvist, Örjan Stål, and those of the panelists who chose to remain anonymous. 
Lastly, we gratefully acknowledge the Nordic-Baltic Centre of Advanced Research on Forestry Serving Urbanised Societies (CARe-FOR-US II) for its encouragement and for fruitful discussions on the findings of the study.

\section{References}

Alcamo J, Hassan R, Bennett E (2003) Ecosystems and human well-being : a framework for assessment / Millennium Ecosystem Assessment. Washington, DC

Bolund P, Hunhammar S (1999) Ecosystem services in urban areas. Ecological Economics 29 (2):293-301

Bryant DL, Abkowitz MD (2007) Estimation of terrestrial chemical spill risk factors using a modified Delphi approach. J Environ Manage 85 (1):112-120

Cortina JM (1993) What Is Coefficient Alpha? An Examination of Theory and Applications. Journal of Applied Psychology 78 (1):98-104

CTLA (2000) Council of Tree \& Landscape Appraisers: Guide for Plant Appraisal (9th ed.). International Society of Arboriculture, Champaign, IL.

Cullen, S. (2002) Tree Appraisal: Can Deprecation Factors be Rated Greater Than 100\%. Journal of Arboriculture 28(3):153-158

Dalkey N, Helmer O (1963) An Experimental Application of the Delphi Method to the use of Experts. Manage Sci 9 (3):458-467

Diem JE, Comrie AC (1998) Estimating biogenic emissions for urban airshed modeling in Tucson, Arizona. Proceedings of the Air \& Waste Management Association's Annual Meeting \& Exhibition

Dimoudi A, Nikolopoulou M (2003) Vegetation in the urban environment: Microclimatic analysis and benefits. Energy and Buildings 35 (1):69-76

Edwards D, Jay M, Jensen FS, Lucas B, Marzano M, Montagné C, Peace A, Weiss G (2012) Public preferences for structural attributes of forests: Towards a pan-European perspective. Forest Policy Econ 19:12-19

Forbes-Laird J (2010) THREATS Tree Hazard: Risk Evaluation and Treatment System. Forbs-Laird Arboricultural Consultancy. http://www.flac.uk.com/wpcontent/uploads/2010/07/THREATS-GN-June-2010.pdf. Accessed 5 April 2012

George D, Mallery P (2008) SPSS for Windows step by step - Eighth edition. Pearson Education, Inc. , USA

Graham B, Regehr G, Wright JG (2003) Delphi as a method to establish consensus for diagnostic criteria. J Clin Epidemiol 56 (12):1150-1156. doi:10.1016/s08954356(03)00211-7

Hsu P (1997) GPS mapping in community resource management: data-acquisition via a barcode interface. Geomatics Info Magazine 11 (9):93-95

i-Tree (2012) i-Tree. http://www.itreetools.org/. Accessed 12th July 2012

Jim, C. Y., Liu, H. H. T. (1997) Storm damage on urban trees in Guangzhou, China. Landscape and Urban Planning 38(1-2):45-59

James P, Tzoulas K, Adams MD, Barber A, Box J, Breuste J, Elmqvist T, Frith M, Gordon C, Greening KL, Handley J, Haworth S, Kazmierczak AE, Johnston M, Korpela K, Moretti M, Niemela J, Pauleit S, Roe MH, Sadler JP, Thompson CW (2009) Towards an integrated understanding of green space in the European built environment. Urban For Urban Green 8 (2):65-75. doi:10.1016/j.ufug.2009.02.001

Keller JKK, Konijnendijk CC (2012) Short communication: A comparative analysis of municipal urban tree inventories of selected major cities in North America and Europe. Arboriculture and Urban Forestry 38 (1):24-30 
Landeta J (2006) Current validity of the Delphi method in social sciences. Technol Forecast Soc Chang 73 (5):467-482

Lonsdale D (1999) Principals of tree hazard assessment and management, vol 7. Forestry commission handbook. Forestry commission, Edinburgh

Maco SE, McPherson EG (2003) A practical approach to assessing structure, function, and value of street tree populations in small communities. Journal of Arboriculture 29 (2):84-97

Martin NA, Chappelka AH, Keever GJ, Loewenstein EF (2011) A 100\% tree inventory using i-tree eco protocol: A case study at Auburn University, Alabama, U.S. Arboriculture and Urban Forestry 37 (5):207-212

Maruthaveeran S, Yaman AR (2010) The identification of criteria and indicators to evaluate hazardous street trees of Kuala Lumpur, Malaysia: A Delphi study. J For 108 (7):360364

Mattheck, C., Breloer, H. (1994) The Body Language of Trees, TSO, London

McPherson EG, Nowak D, Heisler G, Grimmond S, Souch C, Grant R, Rowntree R (1997) Quantifying urban forest structure, function, and value: the Chicago Urban Forest Climate Project. Urban Ecosystems 1 (1):49-61

Miller RW (1997) Urban forestry: Planning and managing urban greenspaces -2nd ed. Prentice-Hall, Inc., USA

Nevo D, Chan YE (2007) A Delphi study of knowledge management systems: Scope and requirements. Inf Manage 44 (6):583-597. doi:10.1016/j.im.2007.06.001

Ningal T, Mills G, Smithwick P (2010) An inventory of trees in Dublin city centre. Irish Geography 43 (2):161-176

Nowak DJ, Crane DE, Stevens JC (2006) Air pollution removal by urban trees and shrubs in the United States. Urban For Urban Green 4 (3-4):115-123

Nowak DJ, Noble MH, Sisinni SM, Dwyer JF (2001) People \& trees - Assessing the US urban forest resource. J For 99 (3):37-42

Okoli C, Pawlowski SD (2004) The Delphi method as a research tool: an example, design considerations and applications. Inf Manage 42 (1):15-29. doi:10.1016/j.im.2003.11.002

Östberg J, Delshammar T, Fransson AM, Nielsen AB (2012a) Standard för trädinventering i urban miljö (Standard for Tree Inventories in Urban Environments). Department of Landscape Management, Design and Construction, LTJ-faculty. LTJ-fakulteten, Alnarp, Sweden

Östberg J, Martinsson M, Stål Ö, Fransson AM (2012b) Risk of root intrusion by tree and shrub species into sewer pipes in Swedish urban areas. Urban Forestry and Urban Greening 11 (1):65-71

Pokorny JD (2003) Urban Tree Risk Management: A Community Guide to Program Design and Implementation. USDA Forest Service - Northeastern Area

Randrup TB (2005) Development of a Danish model for plant appraisal. Journal of Arboriculture 31 (3):114-123

Raupp, M. J., Cumming, A. B., Raupp, E. C. (2006) Street tree diversity in eastern North America and its potential for tree loss to exotic borers. Arboriculture and Urban Forestry 32(6):297-304

Rohrbaugh J (1979) Improving the quality of group judgment: Social judgment analysis and the Delphi technique. Organizational Behavior and Human Performance 24 (1):73-92

Schipperijn J, Pillmann W, Tyrvainen L, Mäkinen K, O’Sullivan R (2005) Information for urban forest planning and management. In: Konijnendijk CC, Nilsson K, Randrup TB, Schipperijn J (eds) Urban forests and trees. Springer, The Netherlands, pp 399-417 
Sjöman H, Nielsen AB (2010) Selecting trees for urban paved sites in Scandinavia - A review of information on stress tolerance and its relation to the requirements of tree planners. Urban For Urban Green 9 (4):281-293

Sjöman H, Östberg J, Bühler O (2012) Diversity and distribution of the urban tree population in ten major Nordic cities. Urban For Urban Green 11 (1):31-39

Smiley ET, Francis RL, Hendrickson N (2007) Tree risk management. Bartlett Tree Research Laboratories

Sreetheran M, Adnan M, Azuar AKK (2011) Street tree inventory and tree risk assessment of selected major roads in Kuala Lumpur, Malaysia. Arboriculture and Urban Forestry 37 (5):226-235

Starr RK (1990) Tree inventory for streetscape planning. Australian Parks \& Recreation 26 (4):23-25,28

Sudol FJ, Zach AL (1987) Managing an urban forest. Public Works 118 (12):42-45

Terho M, Hallaksela AM (2008) Decay characteristics of hazardous Tilia, Betula, and Acer trees felled by municipal urban tree managers in the Helsinki City Area. Forestry 81 (2):151-159. doi:10.1093/forestry/cpn002

Terho M, Hantula J, Hallaksela AM (2007) Occurrence and decay patterns of common wooddecay fungi in hazardous trees felled in the Helsinki City. Forest Pathology 37 (6):420-432

Thomsen P (2012) Bytræer - Diversitet og Forvaltning af By- og Vejtræer i Større Danske Kommuner (Urban Trees - Diversity and management of Urban and Roadside Trees in Larger Danish Municipalities). Copenhagen University, Det natur- og biovidenskabelige fakultet

Todorova A, Asakawa S, Aikoh T (2004) Preferences for and attitudes towards street flowers and trees in Sapporo, Japan. Landsc Urban Plan 69 (4):403-416

UNRI (2010) A field guide Standards for Urban Forestry Data Collection DRAFT 2.0. http://www.unri.org/standards/?page_id=2. Accessed 27 February 2012

Xiao Q, McPherson EG (2002) Rainfall interception by Santa Monica's municipal urban forest. Urban Ecosystems 6 (4):291-302

Yokohari M, Brown RD, Kato Y, Yamamoto S (2001) The cooling effect of paddy fields on summertime air temperature in residential Tokyo, Japan. Landsc Urban Plan 53 (14):17-27 


\section{Appendix 1}

A total of 37 new parameters were suggested. Several other suggestions were made by the panelists, but after discussions amongst the authors these parameters were merged into different 'Free text' parameters because they were not considered capable of standing as individual parameters in the Delphi study. Examples of these parameters were: Use of the wood after cutting the tree down, and Damage to the tree on delivery from the nursery. The decision to add several free text fields resulted in the original free text field being split into 15 new free text groups, which were specific for the different types of parameters. To reduce the number of parameters from 161, thus making the survey somewhat more manageable, 13 parameters were included within existing parameters or were excluded from the list of parameters. The new parameters are marked with an asterisk $(*)$, the parameters that were included in existing parameters are marked with letters in alphabetical order, and deleted parameters are denoted 'Deleted'.

Table 3. Ratings for all parameters in the Delphi study, sorted by mean overall value for all panels (city officials, arborists, and academics) and the mean rating given by the individual panels.

\begin{tabular}{|c|c|c|c|c|c|c|}
\hline $\begin{array}{l}\text { Placemen } \\
\text { t } \\
\text { according } \\
\text { to the } \\
\text { mean } \\
\text { ranking }\end{array}$ & Parameter & $\begin{array}{r}\text { Para } \\
\text { meter } \\
\text { group } \\
(\mathrm{A}-\mathrm{F})\end{array}$ & $\begin{array}{r}\text { Mean } \\
\text { overall } \\
\text { value of } \\
\text { the } \\
\text { three } \\
\text { panels }\end{array}$ & $\begin{array}{r}\text { Mean } \\
\text { city } \\
\text { officia } \\
\text { ls }\end{array}$ & $\begin{array}{r}\text { Mean } \\
\text { academics }\end{array}$ & $\begin{array}{r}\text { Mean } \\
\text { arbori } \\
\text { sts }\end{array}$ \\
\hline 1 & Scientific name of the tree species and genera & $\mathrm{A}$ & $\mathbf{1 0 . 0}$ & 10.0 & 10.0 & 10.0 \\
\hline 2 & Vitality & $\mathrm{B}$ & 9.8 & 9.8 & 9.9 & 9.8 \\
\hline 3 & Coordinates & A & 9.6 & 10.0 & 9.7 & 9.1 \\
\hline 4 & Hazard class & $\mathrm{B}$ & 9.4 & 9.5 & 9.3 & 9.6 \\
\hline 5 & Identification number & $\mathrm{E}$ & 9.2 & 7.8 & 10.0 & 9.8 \\
\hline 6 & Presence of fruit bodies & $\mathrm{B}$ & 9.0 & 8.0 & 9.6 & 9.6 \\
\hline 7 & Date of latest inventory & $\mathrm{E}$ & 9.0 & 9.0 & 10.0 & 7.9 \\
\hline 8 & Category of care & $\mathrm{D}$ & 9.0 & 8.6 & 9.6 & 8.7 \\
\hline 9 & Conservation value & $\mathrm{C}$ & 9.0 & 8.6 & 9.3 & 9.0 \\
\hline 10 & Street or park trees & $\mathrm{A}$ & 8.8 & 9.0 & 9.1 & 8.1 \\
\hline 11 & Age class & A & 8.7 & 7.9 & 9.3 & 9.0 \\
\hline 12 & Stem circumference at 1 metre height at planting & A & 8.7 & 8.9 & 8.4 & 8.7 \\
\hline 13 & Date of planting & $\mathrm{F}$ & 8.6 & 8.1 & 9.3 & 8.4 \\
\hline 14 & Name of disease or pest & $\mathrm{B}$ & 8.5 & 7.3 & 8.4 & 9.7 \\
\hline 15 & Reason for felling & $\mathrm{E}$ & 8.5 & 8.0 & 9.1 & 8.2 \\
\hline 16 & Type of constructed planting site* & $\mathrm{F}$ & 8.4 & 8.4 & 8.7 & 8.0 \\
\hline 17 & Proposed measures & $\mathrm{D}$ & 8.3 & 8.3 & 7.6 & 9.2 \\
\hline 18 & Street address & A & 8.3 & 7.6 & 8.9 & 8.3 \\
\hline 19 & Year of planting & A & 8.2 & 9.4 & 9.0 & 6.3 \\
\hline 20 & Date of update in the database & $\mathrm{E}$ & 8.2 & 8.0 & 9.3 & 7.3 \\
\hline 21 & Presence of stem protection & $\mathrm{A}$ & 8.2 & 7.9 & 9.1 & 7.6 \\
\hline 22 & Soil protection around the tree* & A & 8.1 & 7.4 & 9.0 & 8.0 \\
\hline 23 & Free text on hazard and damages* $(a, b, c)$ & $\mathrm{B}$ & 8.1 & 5.8 & 9.9 & 8.8 \\
\hline 24 & Owner & $\mathrm{E}$ & 8.1 & 7.7 & 8.1 & 8.6 \\
\hline 25 & Date of registration in the database & $\mathrm{E}$ & 8.1 & 8.3 & 9.9 & 6.2 \\
\hline
\end{tabular}




\begin{tabular}{|c|c|c|c|c|c|c|}
\hline 26 & Pruning & $\mathrm{D}$ & 8.1 & 6.5 & 9.1 & 8.7 \\
\hline 27 & Type of planting pit & A & 8.1 & 8.9 & 8.9 & 6.6 \\
\hline 28 & Damage class & B & 8.1 & 7.6 & 9.7 & 6.9 \\
\hline 29 & Protection value & $\mathrm{C}$ & 8.0 & 8.8 & 8.0 & 7.2 \\
\hline 30 & Proposals for action, time & $\mathrm{D}$ & 7.9 & 8.0 & 7.0 & 8.8 \\
\hline 31 & Ground coverage under the tree crown & A & 7.9 & 5.8 & 9.0 & 9.0 \\
\hline 32 & Free text on tree vitality* (a) & B & 7.9 & 5.9 & 9.0 & 8.8 \\
\hline 33 & Swedish name of the tree species and genera & A & 7.9 & 7.8 & 7.7 & 8.1 \\
\hline 34 & Free text on tree damage* (a) & B & 7.8 & 5.8 & 9.6 & 8.2 \\
\hline 35 & Free text on diseases and pests* (a) & B & 7.8 & 4.8 & 9.9 & 8.8 \\
\hline 36 & Free text on the cultural value of the tree* (a) & $\mathrm{C}$ & 7.8 & 4.8 & 9.3 & 9.3 \\
\hline 37 & Mechanical damage* & B & 7.7 & 6.1 & 8.4 & 8.7 \\
\hline 38 & Name of fungus & $\mathrm{B}$ & 7.7 & 6.4 & 7.7 & 9.0 \\
\hline 39 & Date of first inventory & E & 7.7 & 6.6 & 10.0 & 6.4 \\
\hline 40 & Conflict with infrastructure & A & 7.7 & 5.4 & 9.0 & 8.7 \\
\hline 41 & Name of the person who conducted the latest inventory & $\mathrm{E}$ & 7.7 & 6.9 & 9.1 & 7.0 \\
\hline 42 & Maintenance programme & $\mathrm{D}$ & 7.7 & 6.0 & 9.0 & 8.0 \\
\hline 43 & Free text on tree conservation value* (a) & $\mathrm{C}$ & $\mathbf{7 . 6}$ & 4.8 & 9.4 & 8.7 \\
\hline 44 & $\begin{array}{l}\text { Free text concerning the time factor for the maintenance } \\
\text { and operations* (a) }\end{array}$ & $\mathrm{D}$ & 7.4 & 3.3 & 9.4 & 9.7 \\
\hline 45 & City or municipality $(\mathrm{g}, \mathrm{h})$ & E & 7.4 & 6.3 & 7.9 & 8.2 \\
\hline 46 & Protected by law* & $\mathrm{C}$ & 7.4 & 6.0 & 7.3 & 9.0 \\
\hline 47 & Establishment pruning & $\mathrm{F}$ & 7.4 & 5.5 & 7.6 & 9.1 \\
\hline 48 & Free text on new planting of trees* (a) & $\mathrm{F}$ & 7.4 & 3.5 & 9.1 & 9.4 \\
\hline 49 & Type of planting & A & 7.4 & 5.6 & 8.4 & 8.0 \\
\hline 50 & Tree characteristics* & $\mathrm{C}$ & 7.4 & 7.8 & 7.9 & 6.4 \\
\hline 51 & Free text on tree aesthetics* (a) & $\mathrm{C}$ & 7.3 & 4.3 & 9.3 & 8.3 \\
\hline 52 & Damage class, detailed & B & 7.3 & 3.5 & 9.3 & 9.0 \\
\hline 53 & Type of inventory & $\mathrm{E}$ & 7.2 & 5.6 & 8.0 & 8.1 \\
\hline 54 & Ground cover around the tree trunk & A & 7.2 & 5.0 & 8.3 & 8.4 \\
\hline 55 & Need for new plant bed* & $\mathrm{D}$ & $\mathbf{7 . 2}$ & 6.5 & 7.0 & 8.2 \\
\hline 56 & Free text on tree biological values* $(a, d)$ & $\mathrm{C}$ & 7.2 & 4.8 & 8.6 & 8.3 \\
\hline 57 & Salting on the site & A & $\mathbf{7 . 2}$ & 4.8 & 8.9 & 8.0 \\
\hline 58 & Contractor for planting & $\mathrm{F}$ & 7.2 & 7.8 & 6.0 & 7.8 \\
\hline 59 & Infrastructure near the tree & A & 7.1 & 4.5 & 9.1 & 7.8 \\
\hline 60 & Irrigation programme for trees* & $\mathrm{F}$ & 7.1 & 7.9 & 6.1 & 7.3 \\
\hline 61 & Ground cover at planting & $\mathrm{F}$ & 7.1 & 6.4 & 7.3 & 7.6 \\
\hline 62 & Watering during the establishment phase & $\mathrm{F}$ & 7.0 & 5.1 & 8.4 & 7.6 \\
\hline 63 & Registered in the database by: & E & 7.0 & 5.5 & 9.3 & 6.2 \\
\hline 64 & Amount of dieback & B & 7.0 & 5.6 & 9.0 & 6.3 \\
\hline 65 & Nursery & $\mathrm{F}$ & 6.9 & 6.1 & 6.7 & 8.0 \\
\hline 66 & Number of trunks & A & 6.9 & 4.8 & 8.1 & 7.9 \\
\hline 67 & Date of felling & E & 6.9 & 7.6 & 6.3 & 6.8 \\
\hline 68 & Crown diameter & A & 6.9 & 5.4 & 7.3 & 8.0 \\
\hline 69 & Cultural and historical value & $\mathrm{C}$ & 6.9 & 5.3 & 7.4 & 7.9 \\
\hline 70 & Free text on inventory information* $(a, i)$ & A & 6.9 & 3.3 & 9.4 & 7.9 \\
\hline 71 & Person who conducted the first inventory & $\mathrm{E}$ & 6.8 & 5.9 & 9.0 & 5.7 \\
\hline 72 & $\begin{array}{l}\text { Production method (e.g. bare-rooted or balled and } \\
\text { burlapped) }\end{array}$ & $\mathrm{F}$ & 6.8 & 5.4 & 6.7 & 8.4 \\
\hline 73 & Free text on the management of the tree* $(\mathrm{a}, \mathrm{e}, \mathrm{f})$ & $\mathrm{D}$ & 6.8 & 3.5 & 9.4 & 7.6 \\
\hline 74 & Successor* & $\mathrm{C}$ & 6.8 & 5.6 & 7.1 & 7.6 \\
\hline 75 & Disturbance on the site & B & 6.7 & 6.1 & 6.8 & 7.2 \\
\hline 76 & Need for protective measures & $\mathrm{D}$ & 6.7 & 4.1 & 8.3 & 7.6 \\
\hline 77 & Stem protection repair or removal* & A & 6.6 & 6.9 & 6.3 & 6.8 \\
\hline 78 & Air infiltration well* & A & 6.6 & 6.4 & 7.3 & 6.1 \\
\hline 79 & Leaf density and leaf size* & A & 6.6 & 4.5 & 8.7 & 6.6 \\
\hline 80 & Free text concerning the identification and site* (a) & A & 6.6 & 2.6 & 9.4 & 7.7 \\
\hline 81 & Risk of damage due to soil protection grid* & $\mathrm{B}$ & 6.5 & 6.5 & 6.0 & 7.0 \\
\hline 82 & Free text on tree position* (a) & A & 6.5 & 2.8 & 9.1 & 7.6 \\
\hline 83 & Stem height & A & 6.5 & 4.9 & 7.4 & 7.1 \\
\hline
\end{tabular}




\begin{tabular}{|c|c|c|c|c|c|c|}
\hline 84 & Presence of tree support (j) & $\mathrm{F}$ & 6.4 & 4.9 & 6.6 & 7.9 \\
\hline 85 & Date of next scheduled inventory & $\mathrm{E}$ & 6.4 & 5.6 & 6.6 & 7.1 \\
\hline 86 & Person who made the latest update in the database & E & 6.4 & 5.4 & 7.9 & 6.0 \\
\hline 87 & Tree height & A & 6.4 & 4.8 & 7.6 & 6.9 \\
\hline 88 & Free text on tree size* (a) & A & 6.4 & 3.3 & 9.3 & 6.7 \\
\hline 89 & Previous management* & $\mathrm{D}$ & 6.4 & 4.4 & 6.9 & 7.9 \\
\hline 90 & Aesthetic value & $\mathrm{C}$ & 6.4 & 5.1 & 7.4 & 6.6 \\
\hline 91 & $\begin{array}{l}\text { Ground clearance under the tree crown (lowest hanging } \\
\text { branch) }\end{array}$ & A & 6.4 & 3.9 & 8.0 & 7.2 \\
\hline 92 & Control of tree support & $\mathrm{F}$ & 6.3 & 4.3 & 7.0 & 7.6 \\
\hline 93 & Tree size for classes & A & 6.2 & 4.5 & 7.8 & 6.3 \\
\hline 94 & Distance from the tree to the nearest traffic & E & 6.1 & 3.3 & 7.4 & 7.6 \\
\hline 95 & Yearly shoot growth & B & 6.1 & 4.5 & 7.3 & 6.4 \\
\hline 96 & Soil and $\mathrm{pH}$ & A & 6.0 & 3.8 & 8.1 & 6.2 \\
\hline 97 & Location on properties & A & 6.0 & 5.1 & 6.5 & 6.3 \\
\hline 98 & Geographical cultural value of trees* & $\mathrm{C}$ & 5.9 & 4.7 & 7.0 & 6.1 \\
\hline 99 & Road type & $\mathrm{E}$ & 5.9 & 2.9 & 7.7 & 7.2 \\
\hline 100 & Body responsible for tree care & $\mathrm{E}$ & 5.9 & 6.2 & 5.3 & 6.1 \\
\hline 101 & $\begin{array}{l}\text { Proportion of the planting site around the tree that } \\
\text { comprises permeable materials. }\end{array}$ & A & 5.8 & 3.5 & 7.5 & 6.3 \\
\hline 102 & Control of irrigation during the establishment phase & $\mathrm{F}$ & 5.7 & 4.4 & 6.4 & 6.4 \\
\hline 103 & Stem diameter at $1.3 \mathrm{~m}$ height & A & 5.7 & 3.3 & 7.3 & 6.5 \\
\hline 104 & Original tree planting in the historical site* & $\mathrm{C}$ & 5.7 & 4.4 & 5.9 & 6.8 \\
\hline 105 & Stem circumference at $1 \mathrm{~m}$ height & A & 5.4 & 4.5 & 7.1 & 4.7 \\
\hline 106 & Fertilisation programme for the tree $(*)$ & $\mathrm{F}$ & 5.4 & 6.1 & 3.9 & 6.2 \\
\hline 107 & Function on the site & A & 5.4 & 3.0 & 7.0 & 6.1 \\
\hline 108 & Active graves under the tree crown & A & 5.4 & 1.5 & 8.0 & 6.6 \\
\hline 109 & Clone from an older individual $(*)$ & $\mathrm{C}$ & 5.3 & 3.8 & 5.3 & 6.9 \\
\hline 110 & Estimated lifetime & A & 5.3 & 4.5 & 6.3 & 5.0 \\
\hline 111 & Purpose of inventory & $\mathrm{E}$ & 5.2 & 3.9 & 5.3 & 6.4 \\
\hline 112 & Diseases and pests in vicinity of the tree* & B & 5.2 & 3.4 & 4.3 & 7.9 \\
\hline 113 & Check on age when the tree was cut down* & $\mathrm{E}$ & 5.2 & 4.1 & 4.1 & 7.2 \\
\hline 114 & Species suitability for the site & $\mathrm{C}$ & 5.1 & 3.4 & 7.3 & 4.6 \\
\hline 115 & Period of planting & $\mathrm{F}$ & 5.0 & 4.9 & 4.1 & 6.0 \\
\hline 116 & Size of holes on the trunk or branches & $\mathrm{C}$ & 5.0 & 5.0 & 4.4 & 5.6 \\
\hline 117 & Deciduous or conifer & A & 4.9 & 5.9 & 4.3 & 4.4 \\
\hline 118 & Land use (Swedish Environmental Protection Agency) & A & 4.8 & 1.8 & 7.0 & 5.7 \\
\hline 119 & Distance to nearest building/object & A & 4.8 & 2.6 & 6.0 & 5.8 \\
\hline 120 & Stem circumference at $1.3 \mathrm{~m}$ height & A & 4.8 & 4.6 & 5.5 & 4.3 \\
\hline 121 & $\begin{array}{l}\text { Action need (Swedish Environmental Protection } \\
\text { Agency) }\end{array}$ & $\mathrm{D}$ & 4.8 & 3.9 & 3.8 & 6.7 \\
\hline 122 & Female or male clone & A & 4.8 & 3.9 & 6.0 & 4.4 \\
\hline 123 & Distance to nearest house & A & 4.7 & 3.6 & 5.3 & 5.2 \\
\hline 124 & Type of district & E & 4.7 & 2.1 & 5.6 & 6.3 \\
\hline 125 & Environmentally enhancing properties & $\mathrm{C}$ & 4.7 & 2.8 & 6.6 & 4.7 \\
\hline 126 & Planting site with ridges & A & 4.6 & 2.6 & 5.4 & 5.9 \\
\hline 127 & $\begin{array}{l}\text { Characteristics (Swedish Environmental Protection } \\
\text { Agency) }\end{array}$ & $\mathrm{C}$ & 4.6 & 3.8 & 4.6 & 5.6 \\
\hline 128 & Size of the part at risk of falling & B & 4.6 & 3.1 & 5.1 & 5.6 \\
\hline 129 & Architectural suitability & $\mathrm{C}$ & 4.6 & 2.8 & 4.9 & 6.1 \\
\hline 130 & $\begin{array}{l}\text { Proposals for action, time (Swedish Environmental } \\
\text { Protection Agency) }\end{array}$ & $\mathrm{D}$ & 4.5 & 3.6 & 3.8 & 6.2 \\
\hline 131 & Available soil volume & A & 4.4 & 3.8 & 5.3 & 4.2 \\
\hline 132 & Estimated cost of measures & $\mathrm{D}$ & 4.4 & 5.8 & 3.6 & 3.9 \\
\hline 133 & Date of decision to conduct the inventory & $\mathrm{E}$ & 4.4 & 4.1 & 3.9 & 5.1 \\
\hline 134 & Planting site orientation/aspect* & A & 4.3 & 2.6 & 5.7 & 4.7 \\
\hline 135 & Amount of dead wood & $\mathrm{C}$ & 4.3 & 3.6 & 5.1 & 4.2 \\
\hline 136 & Slope under the tree crown & A & 4.2 & 2.5 & 4.6 & 5.7 \\
\hline 137 & Cost of the tree & $\mathrm{F}$ & 4.2 & 3.3 & 3.7 & 5.6 \\
\hline 138 & Job title of the person who carried out the last inventory & $\mathrm{E}$ & 4.1 & 3.9 & 3.8 & 4.6 \\
\hline
\end{tabular}




\begin{tabular}{|c|c|c|c|c|c|c|}
\hline 139 & Visibility & $\mathrm{C}$ & 4.1 & 3.9 & 5.0 & 3.3 \\
\hline 140 & Crown height (lowest branch to the leading shoot) & A & 4.1 & 2.5 & 5.7 & 4.0 \\
\hline 141 & Percentage of crown missing & $\mathrm{B}$ & $\mathbf{4 . 0}$ & 2.3 & 5.7 & 4.2 \\
\hline 142 & Traffic intensity & $\mathrm{E}$ & 4.0 & 2.3 & 5.3 & 4.6 \\
\hline 143 & $\begin{array}{l}\text { Volume of mulm (Swedish Environmental Protection } \\
\text { Agency) (mulm = dead wood, leaves, old bird nests, } \\
\text { etc.) }\end{array}$ & $\mathrm{C}$ & 4.0 & 3.8 & 3.7 & 4.4 \\
\hline 144 & $\begin{array}{l}\text { Purpose of inventory (Swedish Environmental } \\
\text { Protection Agency) }\end{array}$ & $\mathrm{E}$ & 3.8 & 2.8 & 2.4 & 6.1 \\
\hline 145 & Exposure to light & A & 3.7 & 2.1 & 5.0 & 4.0 \\
\hline 146 & Stem diameter at $1 \mathrm{~m}$ height & A & 3.6 & 2.5 & 4.6 & 3.8 \\
\hline 147 & Crown volume & A & 3.2 & 2.3 & 4.7 & 2.8 \\
\hline \multirow[t]{2}{*}{148} & Measuring method for stem diameter/circumference $(*)$ & A & 3.0 & 2.1 & 4.2 & 2.7 \\
\hline & Mean & & 6.5 & 5.3 & 7.3 & 7.0 \\
\hline
\end{tabular}

\section{Deleted}

Angle of the tree to the horizon

Remarks/free text ${ }^{\mathrm{a}}$

Checklist for risk assessment ${ }^{b}$

Tree species risk profile ${ }^{c}$

Environmental valuation method ${ }^{\mathrm{d}}$

Property condition

Proposed moving of the tree ${ }^{e}$

Use of the wood ${ }^{\mathrm{f}}$

City or municipality ${ }^{\mathrm{g}}$

Area/district ${ }^{\mathrm{h}}$

Weather when the inventory was conducted ${ }^{\mathrm{i}}$

Extended control of tree support ${ }^{\mathrm{j}}$

The new parameters are marked with an asterisk $(*)$, the parameters that were included in existing parameters are marked with letters in alphabetical order, and deleted parameters are denoted "Deleted". 